\title{
EVALUATION AND QUANTIFICATION OF HEAT HOTSPOTS IN THE CHAPADA DOS GUIMARÃES-MT NATIONAL PARK
}

\author{
Arlindo de Paula Machado Neto ${ }^{1}$, Antonio Carlos Batista ${ }^{2}$, Ronaldo Viana Soares ${ }^{2}$, Daniela Biondi ${ }^{2}$, Anderson \\ Pedro Bernardina Batista ${ }^{3}$, Angele Tatiane Martins Oliveira ${ }^{4}$ \\ 1 *Federal University of Mato Grosso, Institute of Agricultural and Environmental Sciences, Sinop, Mato Grosso, Brazil - \\ arlindo.neto08@gmail.com \\ ${ }^{2}$ Federal University of Paraná, Department of Forest Sciences, Curitiba, Paraná Brazil - batistaufpr@gmail.com; rvsoares@ufpr.br; \\ dbiondi@ufpr.br \\ ${ }^{3}$ Federal Institute of Education, Science and Technology of Amazonas, Department of Education, São Gabriel da Cachoeira, Amazonas, \\ anderson_pedro22@yahoo.com.br \\ ${ }^{4}$ State University of Mato Grosso, Graduate Program in Ecology and Conservation, Nova Xavantina, Mato Grosso, Brazil - \\ angeleoliveira@gmail.com
}

Received for publication on 17/05/2018 - Accepted for publication on: 14/10/2019

\begin{abstract}
Resumo
Avaliação e quantificação de focos de calor no Parque Nacional da Chapada dos Guimarães-MT. O estudo teve como objetivo analisar a distribuição espacial dos focos de calor no interior e exterior do Parque Nacional da Chapada dos Guimarães (PNCG) no Estado de Mato Grosso. As análises foram realizadas através da estimativa de densidade de kernel (EDK) e da função K de Ripley de 2005 a 2014. Os dados relacionados ao número de focos de calor foram obtidos no Instituto Nacional de Pesquisas Espaciais (INPE) de 2005 a 2014, e os arquivos vetoriais foram adquiridos na base cartográfica do Instituto Brasileiro de Geografia e Estatística (IBGE). Nos 10 anos de análises, foram detectados 579 focos de calor no PNCG, onde se verificou que os meses de agosto e setembro apresentaram as maiores incidências de focos no parque. Os mapas de kernel, demonstraram que a maioria dos focos de calor foram observados nos anos de 2007, 2010 e 2012. Já os anos de 2005 e 2013 apresentaram densidades médias e os anos de 2006, 2008, 2009, 2011 e 2014 indicaram baixa densidade dos focos. A função K de Ripley, calculada para observar a distribuição espacial dos focos de calor, rejeitou a hipótese de completa aleatoriedade espacial (CAE), indicando que os mesmos apresentaram tendência de agrupamento durante a série temporal do estudo no PNCG.
\end{abstract}

Palavras chave: Estimador de kernel, função K de Ripley, incêndios florestais.

\begin{abstract}
The study aimed to analyze the spatial distribution of heat sources inside and outside the Chapada dos Guimarães National Park (PNCG) in the State of Mato Grosso. The analyzes were performed through the estimate of kernel density (KDE) and Ripley's K function from 2005 to 2014. The data related to the number of hot spots were obtained from the National Institute for Space Research (INPE) from 2005 to 2014, and the vector files were acquired from the cartographic base of the Brazilian Institute of Geography and Statistics (IBGE). In the 10 years of analysis, 579 hot spots were detected in the PNCG, where it was found that the months of August and September had the highest incidence of hot spots in the park. The kernel maps demonstrated that most hotspots were observed in the years 2007, 2010 and 2012. The years 2005 and 2013 presented average densities and the years 2006, 2008, 2009, 2011 and 2014 indicated low density of the hot spots. Ripley's K function, calculated to observe the spatial distribution of the hot spots, rejected the hypothesis of complete spatial randomness (CSR), indicating that they showed a tendency to cluster during the study time series at the PNCG.
\end{abstract}

Keywords: Kernel estimator, Ripley's K function, forest fires.

\section{INTRODUCTION}

Every year forest fires cause damage to the economy and biodiversity in several regions of Brazil and the world, constituting one of the greatest threats to the preservation of biodiversity on the planet. In addition to their direct impacts on fauna and flora, they contribute indirectly to environmental degradation, making the soil more susceptible to erosive processes and releasing into the atmosphere a large amount of greenhouse gases (WHITE et al., 2013).

The conversion of forest areas to cultivation areas, in addition to contributing to the increase in deforestation, accentuates the problem of fires, the vast majority of accidents occur after this type of activity, contributing to climate fluctuations and forest fragmentation. (BRANDO et al., 2014).

Due to the rich biodiversity that makes up the national territory, Law No. 9,985 was created in 2000, establishing the National System of Conservation Units (SNUC), and its "conservation objectives and limits

FLORESTA, Curitiba, PR, v. 50, n. 2, p. 1151 - 1160, abr/jun 2020

Machado Neto, A. P. et.al.

ISSN eletrônico 1982-4688

DOI: $10.5380 /$ rf.v50 i2.59471 
defined under special administration", seeking to ensure the preservation of species in areas called Conservation Units (UCs) (BRAZIL, 2000).

The occurrence of fire can be considered a threat and pressure to the CUs, especially those in the Cerrado biome, since they are affected by forest fires that vary in frequency, number and intensity. Therefore, an efficient prevention and control system, with a rapid detection of accidents and the use of effective combat techniques, is necessary to minimize the environmental impacts resulting from the action of fire in these areas. In this context, the need to systematically monitor and quantify fires in vegetation leads to the intensive use of geotechnologies, such as remote sensing and geographical information system (GIS), as tools with the ability to provide information necessary for the process of mapping and interpreting data from heat outbreaks and possible fires (SANTOS, 2017).

With regard to the analysis and mapping of burnt areas in the tropics, from the 1980s onwards, several remote sensing techniques for forest fire prevention, evaluation and monitoring were developed and perfected. These techniques have been employed to address three different temporal phases of fire: fire preconditions, active fire characteristics and post-fire ecosystem responses (CHU; GUO, 2013). To better control forest fires, several countries, such as Brazil, are using remote sensing techniques and geographic information systems to monitor and report on the occurrence of forest fires at a particular location (LIMA HO et al., 2017).

Pereira et al. (2016) Emphasize that geotechnologies emerges as an important tool in the identification of fires, allowing to locate, quantify and perform space-time analysis of the areas where the fire occurs. In this perspective, the spatial analysis of fires contributes significantly to the understanding of them, besides allowing a visual perception of the distribution of the problem addressed. Consequently, the use of geostatistical tools allows the translation of existing standards, configuring itself as a new instrument in helping to control fire. Thereby, this study aimed to analyze the spatial distribution of forest fires in the Chapada dos Guimarães National Park, state of Mato Grosso, from 2005 to 2014, using the kernel density estimator (KDE) and Ripley's K function (RIPLEY, 1977). (RIPLEY, 1977).

\section{MATERIAL AND METHODS}

\section{Characterization of the area}

The study was conducted in the Chapada dos Guimarães National Park (PNCG), which is characterized as a Conservation Unit of integral protection created by Decree $\mathrm{N}^{\circ}$ 97,656, of April 12, 1989. The area has a territorial extension of 32,630 ha distributed in the Cerrado biome (Figure 1). The Park's territory is divided between the municipality of Cuiabá, which is $61.2 \%$, and the rest $(38.8 \%)$ belongs to the municipality of Chapada dos Guimarães. According to Köppen's classification, the region's climate includes the categories Aw (in the Cuiabana Depression) and $\mathrm{Cw}$ (in the Chapada), both have a pre-defined rainy season (October to March) and drought (April to September) (ICMBio, 2009).

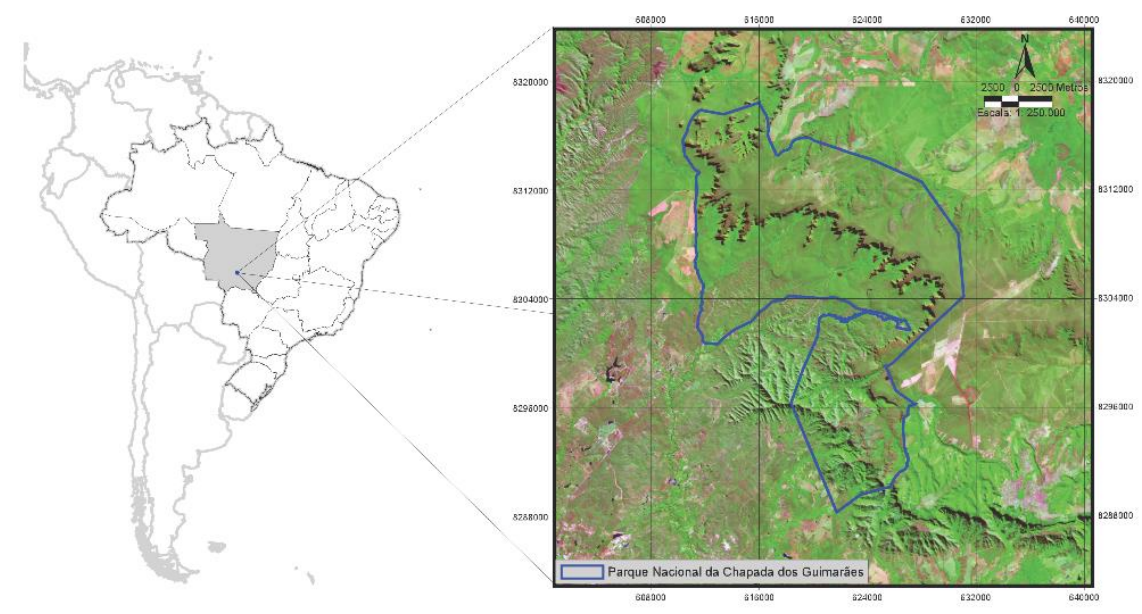

Figure 1. Location map of Chapada dos Guimarães National Park in the State of Mato Grosso.

Figura 1. Mapa de localização do Parque Nacional da Chapada dos Guimarães no Estado de Mato Grosso.

The dry season is characterized by "friagens", a climatic phenomenon characterized by the invasion of polar mass over the continent, leading to sudden drops in temperature. The average annual temperatures vary from $25^{\circ} \mathrm{C}$ in the Baixada Cuiabana and $21.5^{\circ} \mathrm{C}$ in the high tops of Chapada dos Guimarães. The maximum daily

FLORESTA, Curitiba, PR, v. 50, n. 2, p. 1151 - 1160, abr/jun 2020 
temperatures in Baixada Cuiabana can exceed $38^{\circ} \mathrm{C}$, and minimums of $5^{\circ} \mathrm{C}$ were measured at the top of Chapada. Average annual precipitation remains between 1650 and $2100 \mathrm{~mm}$ of rain, with relative humidity, from November to April, below $80 \%$ and, in dry months, below $60 \%$ (ICMBio, 2009).

\section{Land use and occupation}

The legal area of the park is surrounded by several properties, also causing several problems, such as the accumulation of garbage, water pollution, environmental degradation generated by tourists, in visiting points and viewpoints, and the occurrence of forest fires in the surroundings and interior of the park. According to ICMBIO (2009), land use around the PNCG is varied, with a predominance of agriculture, livestock and leisure farms. Santos et al. (2016) Such activities result in direct impacts in the region, causing problems related to the disposal of waste in open air, insufficient basic sanitation, absence of solid waste management, presence of erosive processes, deforestation, increase in the number of fires and disorderly tourism.

Areas with agricultural use in small properties occur around the communities of Coxipó do Ouro, Água Fria, Médico, in the regions of influence of Rios dos Peixe and Aricazinho. This occupation typology is characterized by a set of production systems where predominate the establishment with low and medium technology livestock (dairy farming) predominate and, to a lesser extent, subsistence farming activities, associated with family producers, with the use of rudimentary management. This category of use is still associated with tourism and / or leisure activities (ranch and farms). The areas with agricultural use in medium and large properties with the predominance of pastures occur in a differentiated way, in savannic environments and in a small proportion in forest (IPEM, 2002).

The MT-251 highway that crosses the park's interior also generates an increase in the number of heat sources and consequently in the number of fires, having as causes vehicle exhaust sparks, lit cigarette butts, candles from religious works and vandalism (ICMBio, 2009).

The largest portion of the park's vegetative cover is formed by native vegetation (Figure 2), but there is also, in its interior and surroundings, the presence of areas with dirty pasture composed of exotic vegetation, such as Andropogon grass (Andropogon gayanus Kunth). and brachiaria grass (Brachiaria spp), responsible for the increase in forest fires in the dry season due to the difficulty in fighting fires in this type of vegetation.

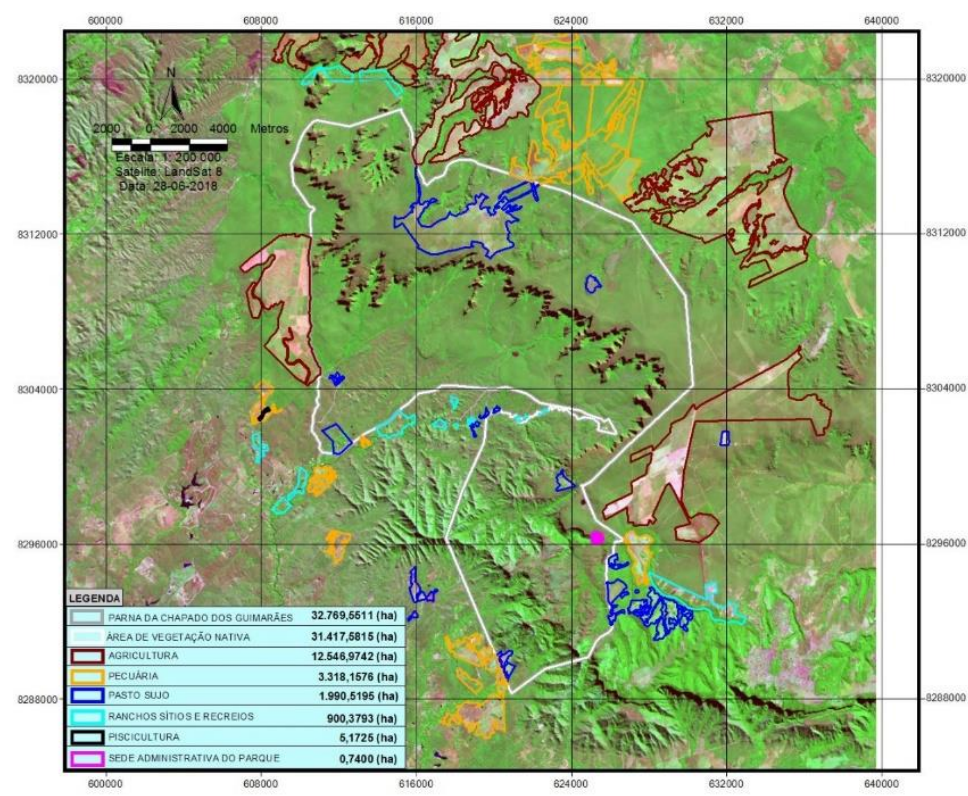

Figure 2. Map of land use and occupation in the Chapada dos Guimarães National Park - MT.

Figura 2. Mapa de uso e ocupação do solo no Parque Nacional da Chapada dos Guimarães - MT.

\section{Data attainment and analysis}

For the interpretation of Landsat 8 images based on the fire occurrence data, the spatial distribution of the heat sources in the park was established and the images were selected in the same period during the 10-year time series (2005 to 2014), using the ArcMap software. The Landsat 8 satellite has been in orbit since 2013 and has two

FLORESTA, Curitiba, PR, v. 50, n. 2, p. 1151 - 1160, abr/jun 2020 
sensors, the Operational Land Imager (OLI) and the Thermal InfraRed Sensor (TIRS). Both have a time resolution of 16 days and the approximate size of each scene is $170 \mathrm{~km}$ by $183 \mathrm{~km}$ (USGS, 2016).

The vector files were acquired from the cartographic database of the Brazilian Institute of Geography and Statistics (IBGE) and the heat source data were obtained from the satellite fire and forest fire monitoring database of the National Institute for Space Research (INPE). The in-situ verification of the fire events in the Park allowed the validation of the heat foci identified by means of the sensors of the satellites derived from the Moderate Resolution Imaging Spectroradiometer (MODIS).

From the heat sources, Kernel density estimation maps (KDE) were made for the inside of the park and in the buffers internal (formed by the buffer zone from the unit limit to the distance of $5 \mathrm{~km}$ ) and external (formed by the buffer zone between the distances of 5 to $10 \mathrm{~km}$ from the unit limit). KDE is characterized as a nonparametric interpolation method, in which the distribution of points is represented by a visual identification surface on the spatial agglomeration patterns of the phenomenon in question, as well as by the way it is distributed in a given region. (BAILEY; GATREALL, 1995). This model is represented by a continuous variation, and two parameters must be taken into account: radius of influence and Kernel estimator function. The influence radius determines the neighborhood of points, used to estimate the value at a point $s$, with $s$ being a generic location in a region $R$, to be interpolated. For the Kernel estimation function, the smoothing property of the exposed phenomenon is used (SILVERMAN, 1986).

The KDE was obtained using the Gaussian estimation function in which the design of the circular neighborhood around the sample points corresponds to the radius of influence, and then a mathematical function of 1 (one) is applied, at the point position, to 0 (zero), at the neighborhood boundary. The value for the cell is the sum of the kernel values overlaid and divided by the area of each search radius (SILVERMAN, 1986). Based on $\mathrm{KDE}$, maps of hot spots corresponding to the years analyzed and a map overlapping the points corresponding to the period from 2005 to 2014 were created.

The densities of the heat sources were obtained through KDE using the Spatial Analyst extension from ArcMap software and software R, developed in the Spatstat package.

To evaluate the spatial distribution of the heat sources, Ripley's K function (1977) was used, which consists of a method based on counting and distance, which uses the coordinates ( $x, y)$ of each event in the study area and evaluates the spatial distribution at different scales simultaneously, bringing greater flexibility in relation to other methods (RIPLEY, 1977). By estimating the K function, it is possible to test the hypothesis of Complete Spatial Randomness (CSR), where the possibility of the spatial distribution pattern of an event behaving in an aggregated, random or regular manner was investigated. CSR was tested using reliable envelopes built by 99 Monte Carlo simulations (DIGGLE, 2003).

In this sense, an analysis was made of the spatial distribution of the hot spots in the PNCG considering a 10-year time series, in which the spots for each year were accumulated to identify the spatial configuration throughout the time series. To calculate Ripley's K function, we use the Spatstat package in software R.

\section{RESULT}

According to data from satellite fire and forest fire monitoring by the National Institute for Space Research (INPE), 579 hot spots were detected in the period from January 2005 to December 2014 in the Chapada dos Guimarães National Park. The years 2007 and 2010 had the highest values with 133 and 213 hot spots, respectively (Figure 3).

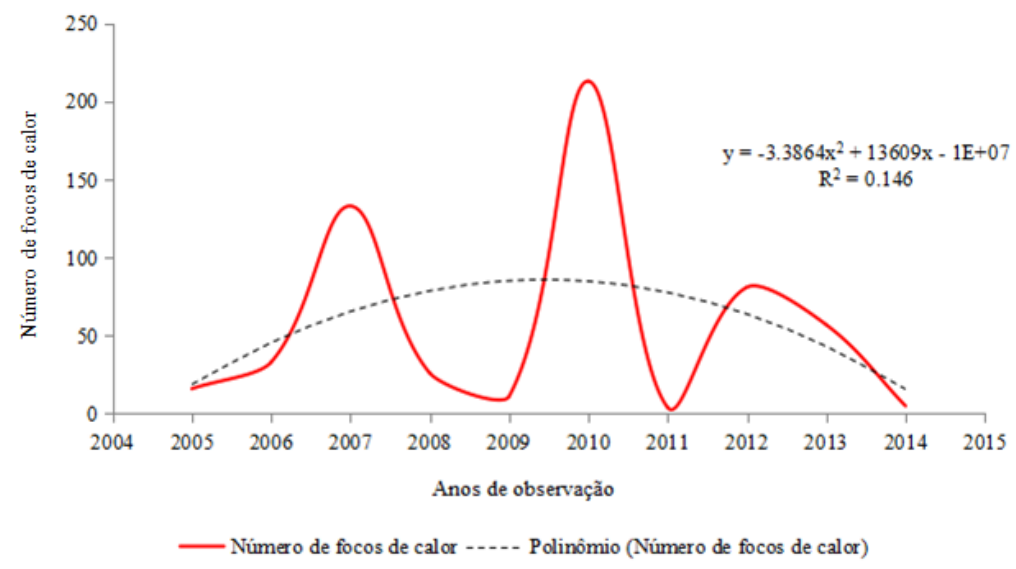


Figure 3. Number of heat sources observed from 2005 to 2014 in the Chapada dos Guimarães National Park-MT. Figura 3. Número de focos de calor observados de 2005 a 2014 no Parque Nacional da Chapada dos Guimarães MT.

The hot spots were also analyzed in relation to the months of the year, where a greater number of them were found in the months of August (210) and September (319), representing 36.27 and 55.09\% respectively and totaling $91,36 \%$ of the outbreaks detected in the analyzed period.

According to the analyzes, there was a trend of growth of hot spots between the months of July and September, with the decline in the months between October and December. Most of the hot spots were concentrated in areas occupied by small rural properties, such as leisure farms around the park, along the roads, close to agricultural areas and pastures, as well as in places of greater tourist attraction.

Figures 4, 5 and 6 show the regions of concentration of the hot spots in the PNCG through the KDE, which allowed an overview of its spatial distribution. Analyzing the kernel density maps, we noticed that the "high" density class, understood in red, had a strong incidence in the interior of the Park in the years 2007, 2010 and 2012. This fact can be explained by the occurrence of major fires in these years. The years 2005 and 2013, on the other hand, presented medium extensions, located inside the Park, represented by the orange color. The low density of outbreaks occurred in the years 2006, 2008, 2009, 2011 and 2014, where the respective fires did not exceed 1000 ha in length.
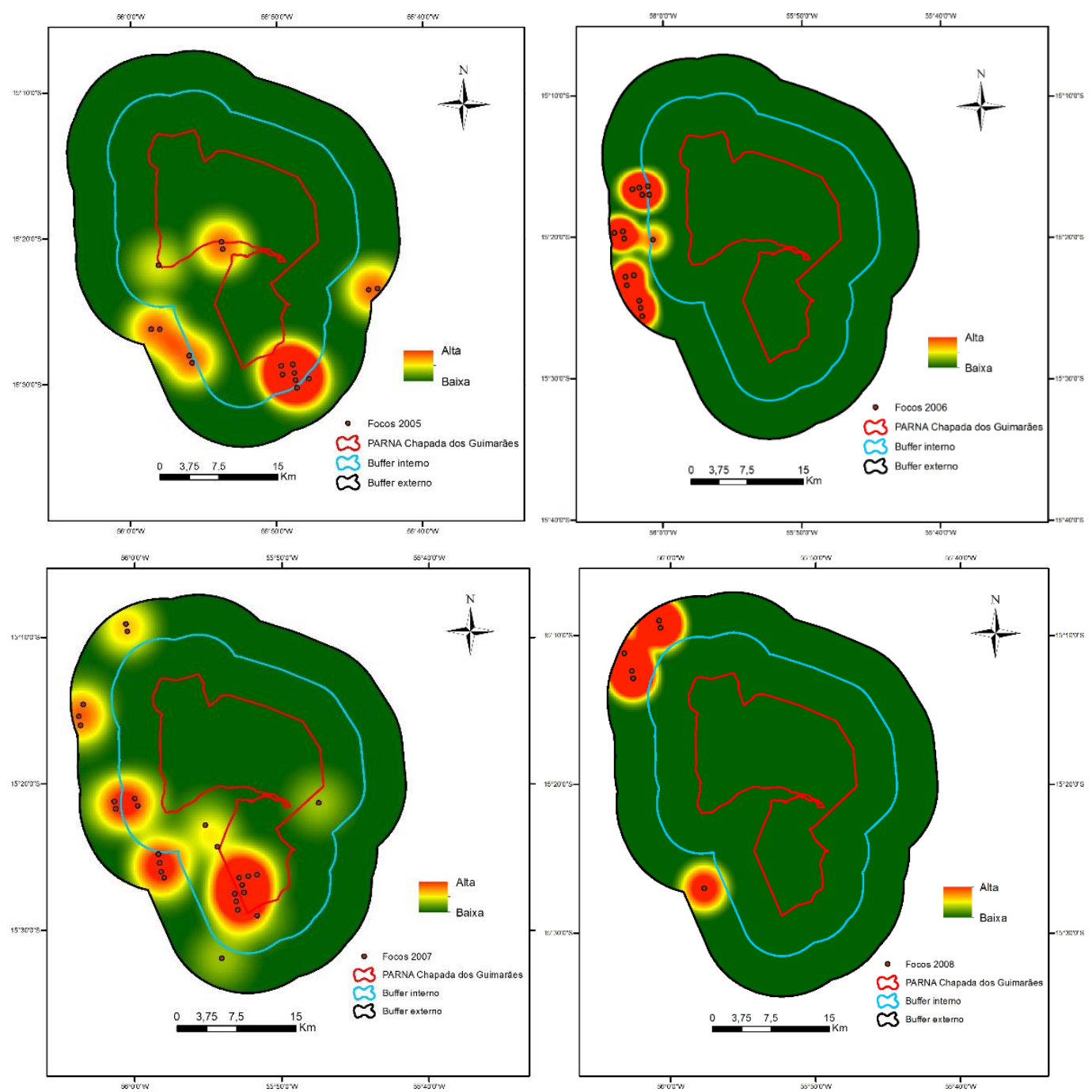

Figure 4. Kernel density map from 2005 to 2008 in the Chapada dos Guimarães National Park -MT.

Figura 4. Mapa da densidade de Kernel de 2005 a 2008 no Parque Nacional da Chapada dos Guimarães -MT.

FLORESTA, Curitiba, PR, v. 50, n. 2, p. 1151 - 1160, abr/jun 2020

Machado Neto, A. P. et.al.

ISSN eletrônico 1982-4688

DOI: $10.5380 /$ rf.v50 i2.59471 

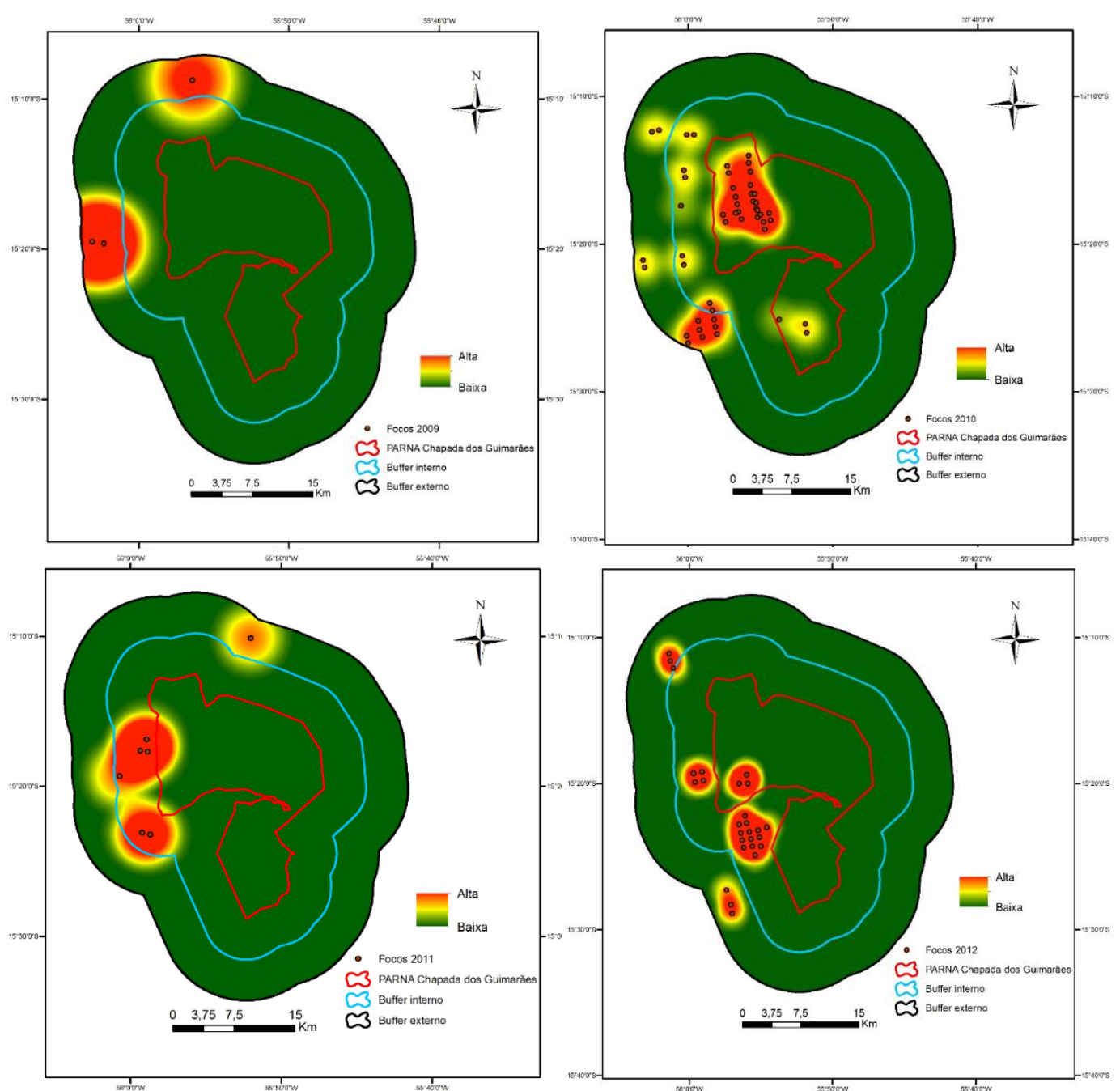

Figure 5. Kernel density map from 2009 to 2012 in the Chapada dos Guimarães National Park -MT.

Figura 5. Mapa da densidade de Kernel de 2009 a 2012 no Parque Nacional da Chapada dos Guimarães -MT.

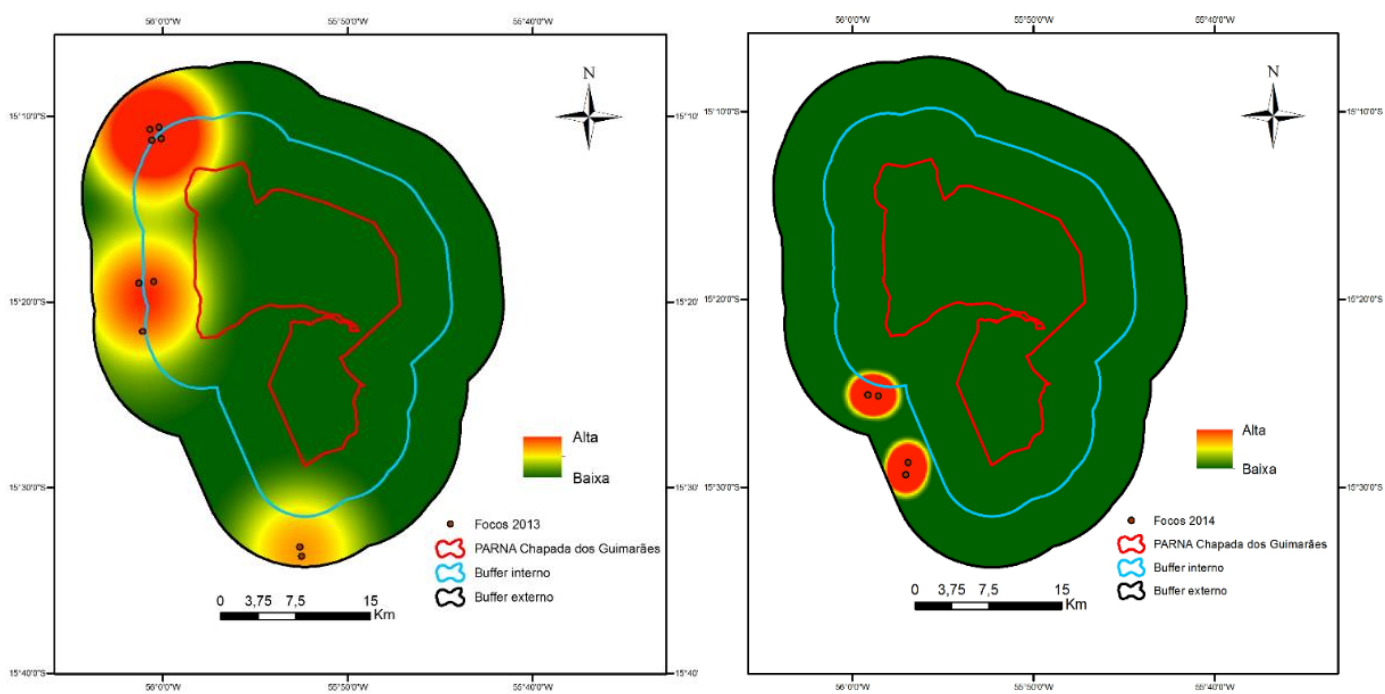

Figure 6. Kernel density map from 2013 to 2014 in the Chapada dos Guimarães National Park -MT.

Figura 6. Mapa da densidade de Kernel de 2013 a 2014 no Parque Nacional da Chapada dos Guimarães -MT.

FLORESTA, Curitiba, PR, v. 50, n. 2, p. 1151 - 1160, abr/jun 2020 Machado Neto, A. P. et.al Electronic ISSN 1982-4688 DOI: $10.5380 /$ rf.v50 i2. 59471 
Figure 7 shows the overlap of the density of the hot spots in the analyzed period. It is possible to infer that the areas where there was a greater density of hot spots are also the areas that presented the biggest fires in the Park. In all years, a high incidence of outbreaks was detected in the PNCG internal and external "buffers", which shows a greater occurrence of fires occurring from outside (surrounding areas) into the Park.

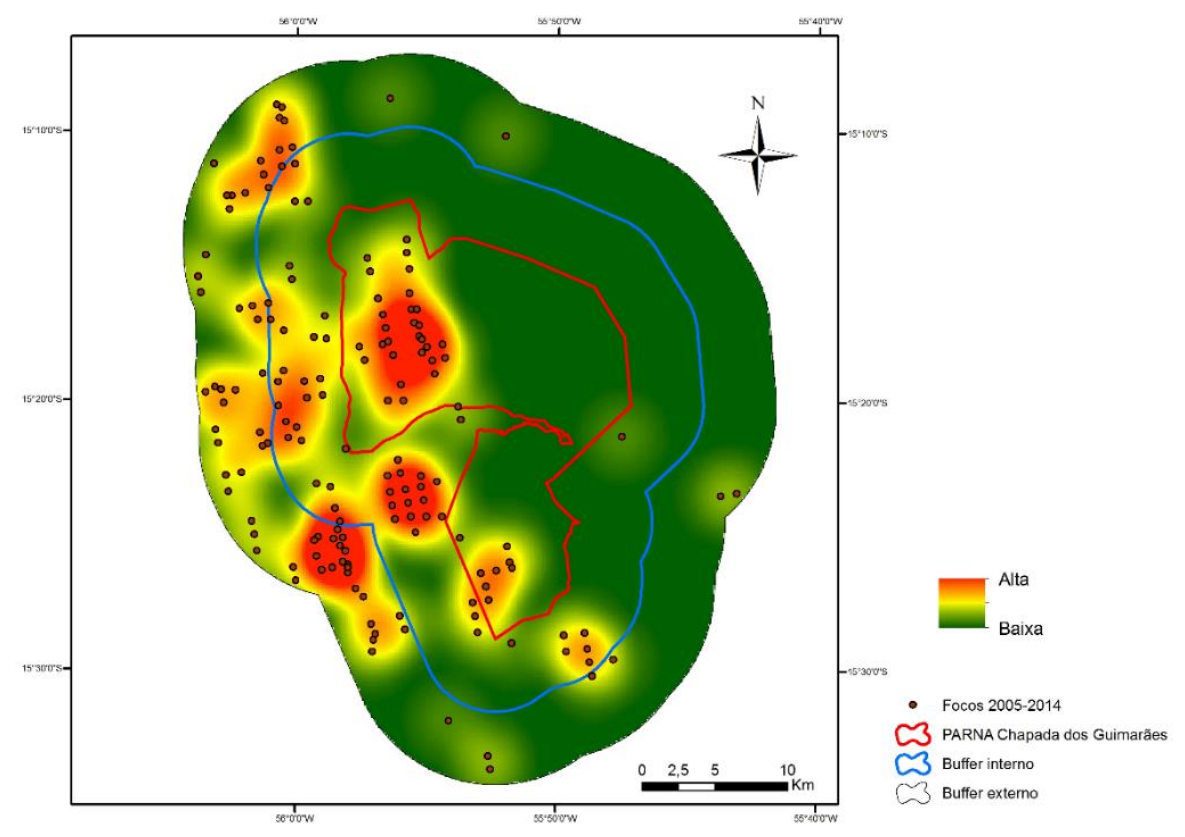

Figure 7. Kernel density map from 2013 to 2014 in the Chapada dos Guimarães National Park-MT. Figura 7. Sobreposição dos mapas de Kernel de 2005 a 2014 no Parque Nacional da Chapada dos Guimarães -MT. 8.

Ripley's K, function for the distribution of heat sources during the 10-year time series is shown in figure

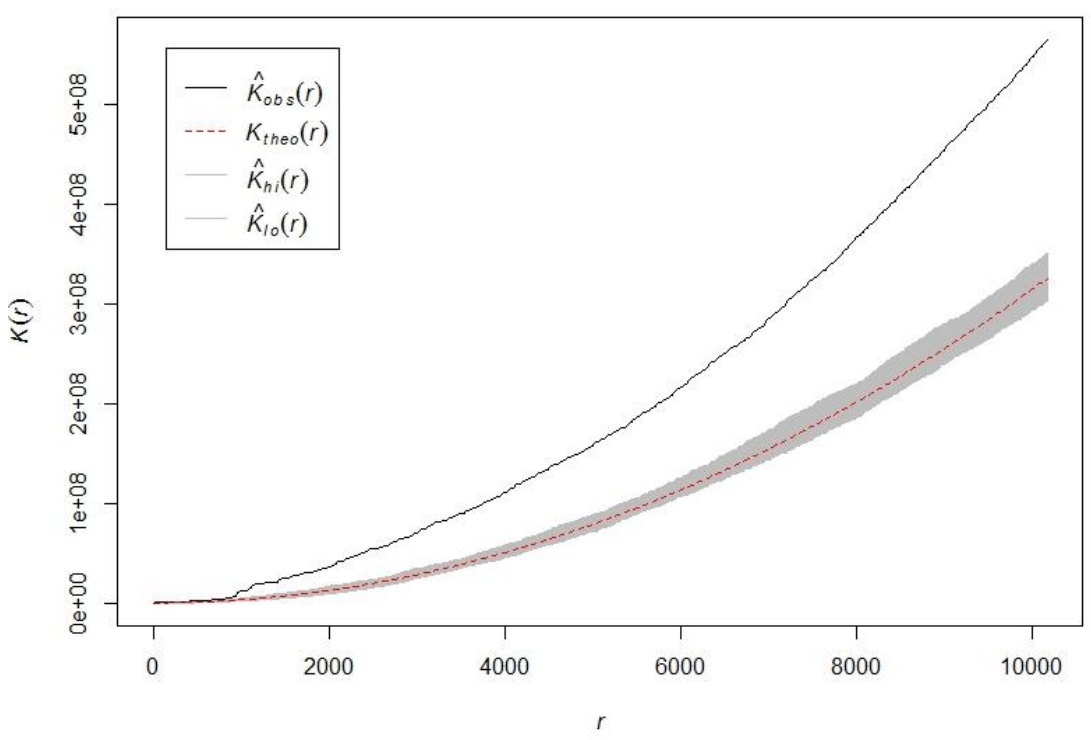

Figure 8. Temporal distribution of heat sources, using Ripley's K function from 2005 to 2014 in Chapada dos Guimarães National Park - MT.

Figura 8. Distribuição temporal dos focos de calor, utilizando a função K de Ripley de 2005 a 2014 no Parque Nacional da Chapada dos Guimarães - MT. 
Values above the upper limit of the confidence envelope indicate a tendency to cluster, values below the dashed line (lower limit of the confidence interval) indicate regularity, and values within the confidence interval indicate spatial randomness (RIPLEY, 1977).

Ripley's K function, calculated to observe the spatial distribution of the hot spots, rejected the hypothesis of complete spatial randomness (CSR), indicating that they showed a tendency to cluster during the 10 years study time series at the PNCG. These results corroborate with the analysis of the kernel estimator in the present study, which also indicated a concentration (higher intensity) of hot spots in the area.

\section{DISCUSSION}

A study carried out in the Chapada dos Veadeiros National Park, in Goiás, showed a lower occurrence of hot spots compared to the present study, with 184 spots inside the unit, through images from the NOAA-12 satellite, in the period from 1992 to 2003 , leading to the finding of a higher incidence of hot spots in relation to the number of occurrences of fires recorded in the park during the analyzed period (FIEDLER; MERLO; MEDEIROS, 2006). This difference in detection in the number of hot spots may be related to the different sensors used in the satellites and the passage period, in addition to the fact that the satellites compute several pixels during a single fire, overestimating the information, as well as false alarms, that is, heat that is not a fire.

The detection of hot spots by remote sensing was evaluated in the Itatiaia National Park using the AQUA satellite, observing the occurrence of 26 spots, concluding that the satellite presented the best results, both in terms of the number of detections and in the proximity of the spots in relation to the affected area (TOMZHINSKI; COURA; FERNANDES, 2011). Within this context, the information related to the accuracy of the satellites in relation to the number of forest fires detected in the field is configured as an important tool so that the managers of the UCs responsible for the prevention of fires can increasingly use this information in decision making.

Records of 1,201 hot spots in the Chapada Diamantina National Park in Bahia were observed between the years 2007 and 2016, verifying that the years with the highest incidence of hot spots in the area were 2008, with 475 hot spots detected, followed by 2015 , with 250 outbreaks detected, and 2012, with 163 outbreaks. The strong incidence of hot spots, in the years 2008 and 2015, may be related to the meteorological phenomena that occurred in these years, or close to them, such as the long drought period and El Niño (SANTOS et al., 2017 ). In the present study, the highest incidence of hot spots was observed in the years 2007 and 2010 with 133 and 213 hot spots, respectively, which reached the interior and surroundings of the park and which were possibly associated with the accumulation of combustible material, caused by the absence of fires of great magnitude in previous years. The areas affected by the fires, in 2007 and 2010, also suggest the occurrence of fires starting from outside to inside the park, considering that the location of the areas affected by the fire in those years were close to regions with livestock use, which they frequently use fire to renew the pasture, becoming an imminent risk in the outbreak of accidents.

In a study carried out in Viçosa-MG, it was observed the occurrence of 79 hot spots between the years 2005 and 2014, where the authors concluded that number of occurrences of fires tends to decrease according to the distance from urban areas, showing the anthropic influence on the start of the event (TORRES et al., 2017). These observations corroborate the present study, considering that the use of fire to clean the land, renew the pasture and burn garbage in the small rural properties located to the south of the park were responsible for most of the fires in the region.

In relation to the months of the year, most of the hot spots were detected in August (210) and September (319), corroborating with Freire and Oliveira (2012) who mapped hot spots for forest fires in Chapada National Park dos Guimarães and also observed a greater concentration in the months of August and September, with a strong correlation between the amount of rain and the number of hot spots, as these two variables showed an inversely proportional correlation, that is, the greater the the amount of rain, the smaller the number of hot spots. Within this context, it was observed that droughts in the months of August and September contributed to the increase in the number of hot spots in the respective months, showing an association between the meteorological conditions of the region and the distribution of the hot spots in the driest periods of the year.

Studies carried out in the Chapada Diamantina National Park found that the majority of hot spots were concentrated in the months of October and November (SANTOS et al., 2017). And yet, probably the volume of $9.4 \mathrm{~mm}$ of rain in October, observed through data from the National Institute of Meteorology for 2008, led to the loss of the photosynthetically active capacity of the vegetation cover, thus contributing to the increased likelihood of fires.

However, the secular distribution of the hot spots, using function $\mathrm{K}$ of Ripley, demonstrated that the aggregate standard observed in the present study, in such a way indicates that the occurrence of a focus increases 
the possibility of occurrence of other hot spots, raising the risk of the accidents. If small fires are considered, we can infer that this pattern may be associated with management practices and conditions of land use.

In relation to the biggest fires, the aggregate pattern is possibly related to the burning for renewal of pasture and cleaning in areas close to the Park, combined with the favorable conditions of propagation (low relative humidity of the air, higher wind speed and vegetation with low content of However, it is noteworthy that other factors may also influence the proportion of a fire, such as the delay in detecting and mobilizing the brigade, in addition to displacement, form of combat and topographic conditions. Areas with high topographic roughness tend to facilitate the dispersion of the fire, increasing the probability of the occurrence of large fires, in addition to limiting access to carry out an efficient combat (GANTEAUME; JAPPIOT, 2013).

A study carried out in the north of the state of Minas Gerais mapped 194 fires that corresponded to an area of 19,538 ha. Fires registered in size classes below 100 ha rejected the hypothesis of Complete Spatial Randomness (CSR), that is, they presented some aggregated distribution pattern along the analysis scale, indicating that some anthropic, biotic or abiotic aspect, favors the grouping of these claims (PEREIRA et al., 2013).

The classes of fires with areas greater than $100 \mathrm{ha}$, in turn, met the CSR hypothesis, that is, they presented a random pattern throughout the analyzed area. Thus, the spatial distribution that differs from randomness deserves to be the object of a detailed analysis (CÂMARA; DAVIS, 2001). In this way, the results obtained suggest an investigation on environmental and social interactions that may elucidate the groupings of hot spots in the Chapada dos Guimarães National Park, thus subsidizing fire prevention programs in its interior and surroundings.

\section{CONCLUSIONS}

- Through the spatial analysis of the distribution of hot spots in the Chapada dos Guimarães National Park, we can consider that the years 2007 and 2010 had the highest concentrations of hot spots and that August and September were the months with the highest rates.

- $\quad$ The kernel estimator detected a high density of outbreaks, in the interior and surroundings of the Park, in the years when there was the incidence of the largest fires, and knowledge about the spatial distribution of fires in the region is essential.

- The results obtained through Ripley's K function indicated that the heat sources tended to cluster during the 10-year time series, thus rejecting the hypothesis of complete spatial randomness of the heat sources.

- Within this context, it is necessary to carry out complementary studies in order to create a risk map according to the characteristics of each region of the Park to understand the structural shape on the distribution of fires in the coming years and, thus, develop plans of mitigation and environmental education in order to prevent the occurrence of fires in an area of such a peculiar nature, such as the Chapada dos Guimarães National Park.

\section{REFERENCES}

BAILEY, TC; GATRELL, AC Interactive spatial data analysis. Essex Longman Scientific \& Technical, 1995.

BRANDO, PM et al. Abrupt increases in Amazonian tree mortality due to drought-fire interactions. Proceedings of the National Academy of Sciences, v. 111, n. 17, p. 6347-6352, 29 apr. 2014.

BRASIL. LEI N . 9.9985, o_Regulamenta o art. 225, § 1ㅇ, incisos I, II, III e VII da Constituição Federal, institui o Sistema Nacional de Unidades de Conservação da Natureza e dá outras providências. Available at: http://www.planalto.gov.br/ccivil_03/LEIS/L9985.htm>. 2000. Accessed on: March 19, 2018.

CÂMARA, G ; DAVIS, C. Introduction to the science of geoinformation. SÃO JOSÉ DOS CAMPOS. Available in: <http://www.dpi.inpe.br/gilberto/livro> Accessed on: March 13, 2018.

CHU, T .; GUO, X. Remote sensing techniques in monitoring post-fire effects and patterns of forest recovery in Boreal forest regions: A review. Remote Sensing, v. 6, n. 1, p. 470-520, 2013.

DIGGLE, PJ (2003). Statistical Analysis of Spatial Point Patterns, 2nd edition. London: Edward Arnold.

FIEDLER, NC; MERLO, DA; MEDEIROS, MB DE. Occurrence of forest fires in the Chapada dos Veadeiros National Park, Goiás. Forest Science, v. 16, n. 2, p. 153, June 302006.

FREIRE, PFB; OLIVEIRA, R. Fire management: multipurpose technical cadastres, constructivist multicriteria decision aid approach, and geographic information systems. case study of Chapada dos Guimarães, state of Mato

FLORESTA, Curitiba, PR, v. 50, n. 2, p. 1151 - 1160, abr/jun 2020

Machado Neto, A. P. et.al.

ISSN eletrônico 1982-4688

DOI: $10.5380 /$ rf.v50 i2.59471 
Grosso, Brazil Management. Revista Brasileira de Cartografia, n. 9, p. 393-405, 2012.

GANTEAUME, A ; JAPPIOT, M. What causes large fires in Southern France. Forest Ecology and Management, v. 294, p. 76-85, 2013.

CHICO MENDES INSTITUTE OF BIODIVERSITY (ICMBIO). Management plan Chapada dos Guimarães National Park. Brasília: ICMBIO, 2009. Available in: <www.icmbio.gov.br/parnaguimaraes/> Access on December, 14th. 2017.

MATOGROSSENSE RESEARCH INSTITUTE (IPEM). Guidelines for the Sustainable Use of the Surroundings of the Chapada dos Guimarães National Park. Technical Report. Cuiabá. 120p. 2002.

LIMA HO, T .; BATISTA, AC; TETTO, AF Forest fire risk forecast for the state of Santa Catarina due to climate changes. Floresta, Curitiba, v. 47, n. 4, p. 427-436, 2017.

PEREIRA, JAV; SILVA, JB Detection of hot spots in the state of Paraíba: a study on fires. Revista Geografia Acadêmica, v.10, n.1, 2016. Available at: https://revista.ufrr.br/rga/article/view/3173 Accessed on: 01 oct. 2018.

PEREIRA, AA et al. Analysis of the spatial distribution of burnt areas using the Ripley K function. Scientia Forestalis, v. 41, n. 100, p. 445-455, 2013.

RIPLEY, BBD Modeling Spatial Patterns. Journal of the Royal Statistic Society, v. 39, n. 2, p. 172-212, 1977.

SANTOS SMB et al. Quantification and spatial analysis of heat sources in the Chapada Diamantina National Park and surroundings in the period from 2007 to 2016. Revista Brasileira de Cartografia, p. 701-712, 2017.

SANTOS, DAS; SILVA, MS; DE BRITO, ALC; REZENDE, GBM, SILVA, FP; BERRÊDO, VCM Proposed Environmental Control Plan and Interpretation of the Degraded Areas Recovery Plan: The Case of the Salgadeira Tourist Complex - Chapada dos Guimarães / MT. R. gest. sust. ambient., Florianópolis, v. 4, n.2, p.345-368, out. 2015 / Mar.2016.

SILVERMAN, BW Density Estimation for Statistics and Data Analysis. Chapaman \& Hall, London, New York, p. $876-877,1986$.

TOMZHINSKI, GW; COURA, PHF; FERNANDES, M. DO C. Evaluation of the detection of hot spots by Remote Sensing for Itatiaia National Park. Brazilian Biodiversity, v. 1, n. 2, p. 201-211, 2011.

TORRES, FTP et al. Mapping the Risk of Forest Fires Using Geoprocessing Techniques. Forest and Environment, v. 24, 2017.

UNITED STATES GEOLOGICAL SURVEY (USGS). Landsat missions: Frequently asked questions about the landsat missions. Available at: http://landsat.usgs.gov//about_project_descriptions.php. Accessed on: March 5, 2016.

WHITE, BLA; WHITE, LAS; RIBEIRO, GT; FERNANDES, PAM Development of a fire danger index for Eucalypt plantations in the northern coast of Bahia, Brazil. Floresta, Curitiba, v. 43, n. 4, p. 601-610, 2013. 